\title{
Producing Black Pepper (Piper nigrum L. cv. 'Kuching') Rootstock in a Deep-Water Culture Hydroponic System
}

\author{
BABIRYE KHADIJAH ${ }^{1}$, PATRICIA KING JIE HUNG**1,2 \& ONG KIAN HUAT ${ }^{1}$
}

\author{
${ }^{1}$ Faculty of Agricultural Science and Forestry, Universiti Putra Malaysia, 97000 Bintulu Sarawak, Malaysia; \\ ${ }^{2}$ Institut Ekosains Borneo, Universiti Putra Malaysia, 97000 Bintulu Sarawak, Malaysia \\ *Corresponding author: patricia@upm.edu.my \\ Received: 29 April $2021 \quad$ Accepted: 2 November $2021 \quad$ Published: 31 December 2021
}

\begin{abstract}
Stem cutting is the common planting material for black pepper (Piper nigrum L.) farmers mainly because the method is cheap, easy to obtain, and produces satisfactory number of new plantlets, which are relatively genetically uniform to their parents. However, soil propagation of stem cuttings renders both the stem and developing roots susceptible to soil borne pathogens, ultimately compromising the quality of the plant. Good quality rootstock of the new plant promotes faster, safer, and better black pepper plant establishment. Hydroponic farming thus offers a good platform for producing quality rootstock of the new plants and has gained importance to many farmers due to its flexibility in manipulating plant growth conditions and timely pathogen management, thus safer, healthier, and faster growth. This study investigated the growing media suitable for rootstock growth of P. nigrum L. cv. 'Kuching' and compared the rooting ability between stem cuttings with adventitious roots at the time of planting and stem cuttings without any root at the time of planting. In a laboratory setting, a total of 210 stem cuttings were hydroponically planted in seven nutrient compositions, with each nutrient composition containing an equal number of stem cuttings with adventitious roots at the time of planting and stem cuttings without any root at the time of planting. Hoagland solution supplemented with $0.005 \mathrm{mM}$ potassium silicate solution (T4) and Hoagland solution supplemented with $2 \mathrm{mM}$ salicylic acid solution (T6) showed faster root initiation whereas T1 (Hoagland solution only) produced the highest increment in root length followed by T6. The least suitable nutrient composition was $\mathrm{T} 5\left[\mathrm{~T} 4+6 \mathrm{~mL}\right.$ of $1 \mathrm{M} \mathrm{Ca}\left(\mathrm{NO}_{3}\right)_{2} \cdot 4 \mathrm{H}_{2} \mathrm{O}$ solution]. The total number of roots was highest in plants from stem cuttings which had some adventitious roots at the time of planting, whereas roots in plants from stem cuttings which did not have any root at the time of planting, increased in root length faster than plants with stem cuttings which had adventitious roots at the time of planting.
\end{abstract}

Keywords: Hoagland solution, potassium silicate, salicylic acid

Copyright: This is an open access article distributed under the terms of the CC-BY-NC-SA(Creative Commons Attribution-NonCommercial-ShareAlike 4.0 International License) which permits unrestricted use, distribution, and reproduction in any medium, for non-commercial purposes, provided the original work of the author(s) is properly cited.

\section{INTRODUCTION}

Popularly known as the 'king of spices', black pepper (Piper nigrum L.) is a perennial vine belonging to family Piperaceae whose berries are highly valued as spice and medicine (Zhigang et al., 2010; Ahmad et al., 2012; Meghwal \& Goswami, 2013). It is widely cultivated in many countries all over the world, including Malaysia (Sivaraman et al., 1999). The cultivars commonly grown in Malaysia include Semenggok Emas, Semenggok Aman, Semenggok Perak and Kuching. Kuching is the traditional cultivar, with high yields, most preferred variety for creamy white pepper production but with the thinnest pericarp and highly prone to major root parasites and diseases for example root-knot nematodes (Megir \& Paulus, 2011). Such root parasites severely damage black pepper roots ultimately causing poor development of the plant root stock
(Megir \& Paulus, 2011) which negatively impacts black pepper yields (Ravindra et al., 2014).

Black pepper is a shade-loving crop and develops physiological disorders once exposed to direct solar radiation, even if the soil moisture conditions are ideal (Vjayakumar et al., 1984; Vjayakumar \& Mammen, 1990). It neither tolerates too high nor too low temperatures and the optimum soil temperature for its root growth is $26-28^{\circ} \mathrm{C}$ (De Waard \& Zeven, 1969; Wahid \& Sitepu, 1987). According to Zhigang et al. (2010), temperature has a significant effect on radical length of black pepper seeds during germination. Additionally, evidence that nutrient and water uptake from the roots are affected by the nutrient solution/soil temperature is well documented (Pregitzer \& King, 2005; Rachelle et al., 2009; Andreas et al., 2019).

Black pepper requires an optimum supply of 
both macronutrients and micronutrients for productive yield (Ann, 2012; Kevin et al., 2018). According to Srinivasan et al. $(2007 ; 2012)$, the major nutrients required by black pepper are $\mathrm{N}, \mathrm{P}$, $\mathrm{K}$, followed by secondary nutrients $\mathrm{Ca}$ and $\mathrm{Mg}$. Nerrisa et al. (2018) estimated a three-fold increment in black pepper yields from high yielding cultivars i.e., Kuching, Semenggok Emas, and Semenggok Aman if proper nutritional management is not compromised. To this end, Srinivasan et al. (2012) pinpoints that a clear understanding of black pepper's nutrient dynamics coupled with timely provision of essential nutrients are key components in achieving sustainable black pepper yields.

Promotion of root development by salicylic acid and silicon fertilisation has been reported in many studies. Salicylic acid (SA) is a phenolic compound that regulates plant growth and development in various aspects, including nutrient uptake, root initiation and growth (Khan et al., 2015; Wani et al., 2016; Pasternak et al., 2019). Plant exposure to exogenous SA promotes development of adventitious, primary and lateral roots in many plants (Yang et al., 2013; Pasternak et al., 2019). In the same vein, improved beneficial effects to plants in response to silicon fertilization is well-documented (Laane, 2018); including its regulatory role in the uptake of other plant nutrients (Ma \& Yamaji, 2006; Liang et al., 2007; Al-Wasfy, 2013; Deshmukh et al., 2017).

Because black pepper is both a nutritionally demanding and weather-sensitive crop (Srinivasan et al., 2012), hydroponic farming seems a better cultivation method to produce new plants in overcoming the adverse effects of sudden weather, soil nutrition and $\mathrm{pH}$ uncertainties that would compromise the new plant's quality. Hydroponic farming involves cultivation of crops in a soilless medium (Eduardo et al., 2015; De Souza et al., 2018; Wada, 2019), in which the plant's growth conditions are manipulated in real-time as desired by the farmer (Sambo et al., 2019). It is a positive response towards a friendlier agriculture in comparison with soil-based farming (Islam et al., 2018; Sambo et al., 2019; Wada, 2019) and has gained much attention worldwide, notably in vegetable production (De Souza et al., 2018; Spehia et al., 2018; Sambo et al., 2019). This timely 'manipulation' of growth conditions translates into safer, healthier, and faster growth rate. Furthermore, hydroponic cultivation guarantees commencement of the crop production cycle in absence of soil-borne pests and diseases, allows for a more detailed analysis of the whole root system in addition to easier monitoring of root growth which facilitates timely pest management and thus promoting production of good quality rootstock of the new plant (Amalfitano et al., 2017; Pignata et al., 2017; Spehia et al., 2018).

However, one of the most vital aspects of hydroponics is the nutrients' composition and concentration added to the system (Libia \& Fernando, 2012; Valentinuzzi et al., 2015; Lee et al., 2017); any compromise results in poor yield (quality and quantity). As the hydroponic nutrient solution is the sole source of nutrients for the hydroponic plant, it is thus imperative to supply a balanced solution that contains all plant nutrients, in the right balance (Lee et al., 2017; Wada, 2019). In hydroponic systems, plant productivity is closely related with nutrient uptake and $\mathrm{pH}$ regulation (Marschner, 1995). Hoagland's solution (1950) is a standardized nutrient medium that was developed in an attempt to ensure adequate nutrition for a wide variety of hydroponically grown plants experimentally; it provides the minimum parts per million ( $\mathrm{ppm}$ ) needed of each element for healthy plant growth to occur (Zabel et al., 2019). Just like in soil cultivation, it is paramount that temperature of the growing media is maintained within the optimum range in a hydroponic system. Temperature of the root environment significantly impacts root growth and behaviour; high temperatures increase diffusion of dissolved oxygen from the hydroponic system (Graves, 1983).

In the present era where hydroponic farming has gained much importance to many farmers (Libia \& Fernando, 2012; De Souza et al., 2018; Sambo et al., 2019), it is paramount that the nutritional requirements of hydroponic black pepper ( $P$. nigrum L.), that can promote optimal growth especially of the root system are established. The present study therefore aimed at developing hydroponic solutions for black pepper ( $P$. nigrum L. cv. 'Kuching') and the specific objectives were to establish the i) suitable growing medium for root stock development of hydroponic P. nigrum L. cv. 'Kuching'; ii) suitable stem cuttings for hydroponic $P$. nigrum L. cv. 'Kuching' by comparing stem cuttings with adventitious roots and stem cuttings without any root at the time of planting. 


\section{MATERIALS AND METHODS}

Freshly harvested healthy black pepper $(P$. nigrum L. cv. 'Kuching') stem cuttings (with no symptoms of mineral deficiency, disease or insect damage) were obtained from the Malaysian Pepper Board. These stem cuttings were harvested during the same period from mother plants which were 2.5 years old, from the same $P$. nigrum $L$. cv. 'Kuching' farm. Nutrient salts used in the present study include Hoagland's No. 2 basal salt mixture powder (Sigma-Aldrich, USA), SA (Merck, China), potassium silicate (sigma-Aldrich, Canada), among others. This study was conducted at the Centre of Excellence, Plant Health and Diagnostic Laboratory, Universiti Putra Malaysia Kampus Bintulu. Black pepper stem cuttings were hydroponically planted in the laboratory (Figure 1) by filling the growing trays $(34 \mathrm{~cm}$ diameter each) with $10 \mathrm{~L}$ of the Nutrient solution (NS), maintaining the electrical conductivity (EC) and $\mathrm{pH}$ in ranges of $1.8-2.5 \mathrm{mS} / \mathrm{cm}$ and 5.8-6.3, respectively and supplying the NS with dissolved oxygen through powered aeration with air pumps and air stones, employing the deep-water culture method (Figure 2). Each growing tray initially contained two air stones, and a third air stone was later added to each growing tray at week 2 (due to an observed characteristic root browning coinciding with an increase in the total number of roots and root length). The media temperature was maintained at $28^{\circ} \mathrm{C}$. Black pepper cuttings were recut slantwise on the lower end with an alcoholdisinfected pruning shear (to avoid contamination), quickly coated with a thin layer of talcum powder containing rooting hormone (Indole Butyric Acid powder- to hasten root initiation and to increase the number of roots produced per cutting) at the cut end, gently rested in meshed cups and supported in an upright position by sponge cubes. The cuttings in meshed cups were submerged into growing trays containing NS, to a depth of $2.5 \mathrm{~cm}$ and supported above the growing tray by polystyrene (Figure 1). All growing trays were arranged in a completely randomized design on the laboratory table.

A total of 210 plants were propagated and involved both stem cuttings with adventitious roots (mean length of $2.01 \mathrm{~cm}$ ) and stem cuttings without any root. Stem cuttings with 3-4 nodes were used in this study. The NS, EC and $\mathrm{pH}$ were monitored daily, and timely adjustments were made accordingly (if out of the recommended range). Each growing tray was topped up with distilled water every after a $15 \%$ NS reduction. Fresh NS was provided to a growing tray, every after the total amount of topped-up water had reached half the original volume of the NS. Plant-response data was collected every after two weeks for a total period of a month and assessed for the following growth variables; (i) total number of roots and (ii) root length. Root length was measured using a measuring tape expressed in centimetres. A cutting was considered rooted when it produced at least 5 $\mathrm{mm}$ length of the root.

This study tested seven media compositions (Table 1) with 30 black pepper plants/stem cuttings per treatment. Hoagland solution (T1) was used as a baseline formulation. Data was log transformed and analysed using the SAS software, version 9.4. Mean separations were performed through the Duncan's multiple range test, with reference to 0.05 probability level.

\section{RESULTS AND DISCUSSION}

\section{Feasibility of the Hydroponic Solutions on Plant Performance}

Among the treatment compositions investigated, $P$. nigrum L. cv. 'Kuching' cuttings cultivated in T4 (Hoagland solution supplemented with $0.005 \mathrm{mM}$ potassium silicate solution) and T6 (Hoagland solution supplemented with $2 \mathrm{mM}$ SA solution) produced the highest total number of roots at week 2 (Table 2). However, the performance of hydroponic solutions T1 (Hoagland solution), T2 (Hoagland solution supplemented with $1 \mathrm{M} \mathrm{KNO}_{3}$ ) and T7 [Hoagland solution supplemented with 6 $\mathrm{mL}$ of $1 \mathrm{M} \mathrm{Ca}\left(\mathrm{NO}_{3}\right)_{2} \cdot 4 \mathrm{H}_{2} \mathrm{O}$ and $2 \mathrm{mM} \mathrm{SA}$ solution] can also be considered as satisfactory as they produced similar number of roots when reached week 4. T3 [Hoagland solution supplemented with $\left.1 \mathrm{M} \mathrm{Ca}\left(\mathrm{NO}_{3}\right)_{2} \cdot 4 \mathrm{H}_{2} \mathrm{O}\right]$ underperformed as compared to the other treatments, as it presented the fewest total number of roots at the end of the experiment.

Plants cultivated in T4 and T6 produced the longest increment of roots length when reached week 2 (Figure 3). However, towards week 4, Hoagland solution (T1) outperformed other treatments. T5 [Hoagland solution supplemented with $1 \mathrm{M} \mathrm{Ca}\left(\mathrm{NO}_{3}\right)_{2} .4 \mathrm{H}_{2} \mathrm{O}$ and $0.005 \mathrm{mM}$ potassium silicate solution] had the poorest performance in root extension and presented the shortest roots at the end of the experiment. The performance of Hoagland solution (T1) was satisfying in the present study. 


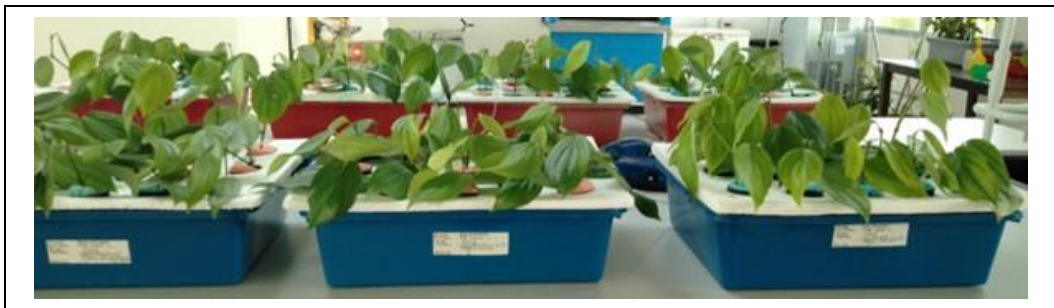

Figure 1. Hydroponic system set-up in the laboratory

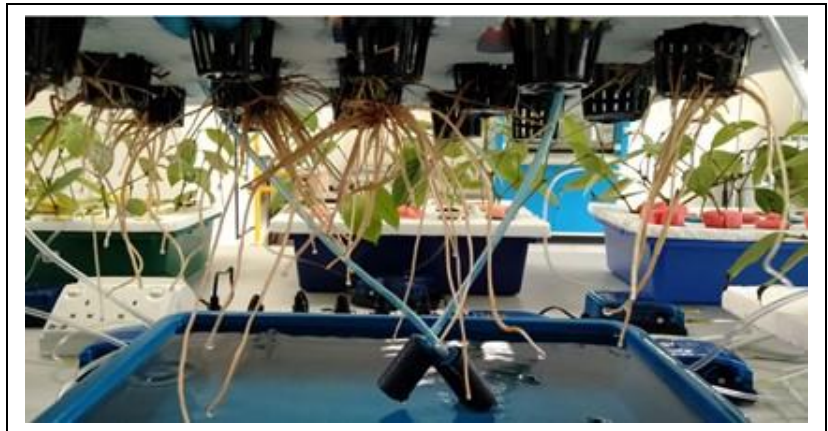

Figure 2. Deep water culture hydroponic aeration with powered air pumps and stones

Table 1. Nutrient composition for the different treatments

\begin{tabular}{cl}
\hline Treatment & Composition \\
\hline $\mathrm{T} 1$ & Hoagland solution \\
$\mathrm{T} 2$ & $\mathrm{~T} 1+6 \mathrm{~mL}$ of $1 \mathrm{M} \mathrm{KNO}_{3}$ in each Liter of Hoagland solution \\
$\mathrm{T} 3$ & $\mathrm{~T} 1+6 \mathrm{~mL}$ of $1{\mathrm{M} \mathrm{Ca}\left(\mathrm{NO}_{3}\right)_{2} .4 \mathrm{H}_{2} \mathrm{O} \text { in each Liter of Hoagland solution }}_{\mathrm{T} 4}^{\mathrm{T} 1+0.005 \mathrm{mM} \text { potassium silicate in each Liter of Hoagland solution }}$ \\
$\mathrm{T} 5$ & $\mathrm{~T} 3+0.005 \mathrm{mM}$ potassium silicate in each Liter of Hoagland solution \\
$\mathrm{T} 6$ & $\mathrm{~T} 1+2 \mathrm{mM} \mathrm{SA}$ solution in each Liter of Hoagland solution \\
$\mathrm{T} 7$ & $\mathrm{~T} 3+2 \mathrm{mM} \mathrm{SA}$ solution in each Liter of Hoagland solution \\
\hline
\end{tabular}

Table 2. Total number of roots of experimental plants from week 0 -week 4

\begin{tabular}{lccc}
\hline \multirow{2}{*}{$\begin{array}{l}\text { Treatment } \\
\text { composition }\end{array}$} & \multicolumn{2}{c}{ Total number of roots after log transformation } \\
\cline { 2 - 4 } & Week 0 & Week 2 & Week 4 \\
\hline T1 & $3.30 \pm 1.15^{\mathrm{a}, 2}$ & $3.69 \pm 0.03^{\mathrm{b}, 2}$ & $4.69 \pm 1.02^{\mathrm{a}, 1}$ \\
T2 & $3.37 \pm 1.14^{\mathrm{a}, 2}$ & $3.47 \pm 0.03^{\mathrm{b}, 2}$ & $4.43 \pm 1.01^{\mathrm{a}, 1}$ \\
T3 & $2.94 \pm 0.99^{\mathrm{a}, 2}$ & $3.47 \pm 0.03^{\mathrm{b}, 2}$ & $4.02 \pm 0.09^{\mathrm{b}, 1}$ \\
T4 & $3.43 \pm 1.10^{\mathrm{a}, 2}$ & $4.38 \pm 1.09^{\mathrm{a}, 1}$ & $4.64 \pm 1.07^{\mathrm{a}, 1}$ \\
T5 & $2.20 \pm 0.01^{\mathrm{b}, 3}$ & $3.40 \pm 0.00^{\mathrm{b}, 2}$ & $4.28 \pm 0.68^{\mathrm{ab}, 1}$ \\
T6 & $3.09 \pm 1.13^{\mathrm{a}, 2}$ & $4.62 \pm 0.10^{\mathrm{a}, 1}$ & $4.90 \pm 1.00^{\mathrm{a}, 1}$ \\
T7 & $3.00 \pm 1.00^{\mathrm{a}, 3}$ & $3.87 \pm 0.04^{\mathrm{b}, 2}$ & $4.49 \pm 1.02^{\mathrm{a}, 1}$ \\
\hline
\end{tabular}




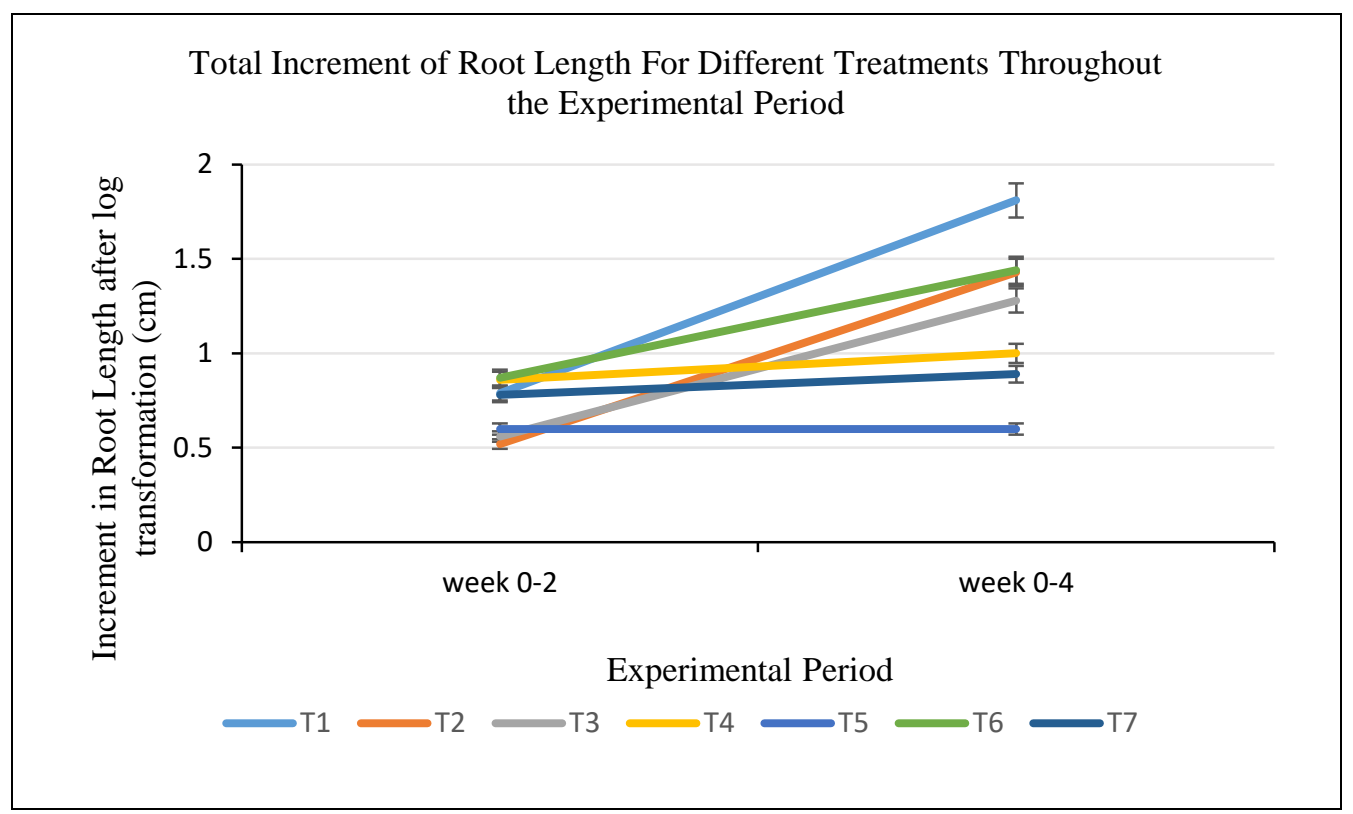

Figure 3. Root length of experimental plants in each treatment throughout the experimental period

\section{Feasibility of the Presence or Absence of Adventitious Roots on the Planting Material}

A growth comparison was made between plants whose stem cuttings had some adventitious roots at the time of planting $(\mathrm{R})$ with similar plants whose stem cuttings did not have any root at the time of planting (U). At week 4, the total number of roots in plants from $\mathrm{R}$ cuttings were higher than those plants from $\mathrm{U}$ cuttings (Table 3 ).

From the result of the experiment (Table 4), U cuttings had faster increment in root number than $\mathrm{R}$ cuttings from week 0 to week 2 . In the subsequent fortnight, the increment slowed down and the advantage of $U$ cuttings disappeared in all treatments. However, in terms of root length (Table 5), U cuttings had significant better increment than $\mathrm{R}$ cuttings in all treatments.

One of the most vital aspects of hydroponics is the nutrients' composition and concentration added to the system and its compromise results into poor growth (Libia \& Fernando, 2012; Valentinuzzi et al., 2015; Lee et al., 2017). Based on the results obtained, hydroponic solutions T6 (Hoagland solution supplemented with $2 \mathrm{Mm}$ SA solution) and Hoagland solution supplemented with 0.005 $\mathrm{mM}$ potassium silicate solution (T4) showed faster root initiation and extension for $P$. nigrum L. plants produced using a deep-water culture technique.
Better root system is essential for black pepper as it would enhance nutrient uptake and subsequently promote growth. As noted by previous research, optimising the supply of both macronutrients and micronutrients increases growth plus the productive yield of black pepper (Ann, 2012; Kevin et al., 2018).

Salicylic acid is a phenolic compound that regulates plant growth and development in various aspects, including nutrient uptake, root initiation and growth (Khan et al., 2015; Wani et al., 2016; Pasternak et al., 2019). Evidence that exogenous SA promotes root initiation in different crops especially at low concentrations is welldocumented (Khan et al., 2015; Wani et al., 2016; Pasternak et al., 2019). Exogenous SA application at different doses promotes development of adventitious, primary and lateral roots in many plants including pea (Pisum sativum) (Yang et al., 2013; Pasternak et al., 2019). In their analysis of the effect of SA on Arabidopsis thaliana root development, Pasternak et al. (2019) observed that at low concentrations (below $50 \mu \mathrm{M}$ ), exogenous SA regulated root development; it both promoted growth of well-developed adventitious roots and altered architecture of the root apical meristem. However, the threshold between low and high exogenous SA concentrations depends on the plant species in question and the method of treatment i.e., foliar spraying, soil drenching and as a hydroponic 
Table 3. Comparison of the total number of roots between plants whose stem cuttings had some adventitious roots at the time of planting and plants whose stem cuttings did not have any root at the time of planting

\begin{tabular}{|c|c|c|c|c|c|c|c|c|}
\hline \multirow{2}{*}{$\begin{array}{l}\text { Weeks } \\
\text { after } \\
\text { planting }\end{array}$} & & \multicolumn{7}{|c|}{ Total number of roots after $\log$ transformation } \\
\hline & & T1 & $\mathbf{T 2}$ & T3 & $\mathbf{T 4}$ & T5 & T6 & T7 \\
\hline \multirow[t]{2}{*}{ Week 0} & $\mathrm{R}$ & $3.33 \pm 0.30^{\mathrm{a}}$ & $3.40 \pm 0.26^{\mathrm{a}}$ & $2.30 \pm 0.18^{\mathrm{a}}$ & $3.47 \pm 0.21^{\mathrm{a}}$ & $2.30 \pm 0.16^{\mathrm{a}}$ & $3.13 \pm 0.24^{\mathrm{a}}$ & $3.04 \pm 0.22^{\mathrm{a}}$ \\
\hline & $\mathrm{U}$ & $0.00 \pm 0.00^{\mathrm{b}}$ & $0.00 \pm 0.00^{\mathrm{b}}$ & $0.00 \pm 0.00^{\mathrm{b}}$ & $0.00 \pm 0.00^{\mathrm{b}}$ & $0.00 \pm 0.00^{\mathrm{b}}$ & $0.00 \pm 0.00^{\mathrm{b}}$ & $0.00 \pm 0.00^{b}$ \\
\hline \multirow[t]{2}{*}{ Week 2} & $\mathrm{R}$ & $3.99 \pm 0.30^{\mathrm{a}}$ & $4.04 \pm 0.31^{\mathrm{a}}$ & $3.37 \pm 0.21^{\mathrm{a}}$ & $4.13 \pm 0.32^{\mathrm{a}}$ & $3.64 \pm 0.20^{\mathrm{a}}$ & $4.26 \pm 0.30^{\mathrm{a}}$ & $3.09 \pm 0.20^{\mathrm{a}}$ \\
\hline & $\mathrm{U}$ & $2.08 \pm 0.11^{\mathrm{b}}$ & $2.64 \pm 0.07^{\mathrm{b}}$ & $2.40 \pm 0.13^{\mathrm{b}}$ & $2.30 \pm 0.11^{\mathrm{b}}$ & $2.20 \pm 0.10^{\mathrm{b}}$ & $3.00 \pm 0.21^{\mathrm{b}}$ & $2.56 \pm 0.10^{b}$ \\
\hline \multirow[t]{2}{*}{ Week 4} & $\mathrm{R}$ & $4.72 \pm 0.37^{\mathrm{a}}$ & $4.65 \pm 0.15^{\mathrm{a}}$ & $4.02 \pm 0.33^{\mathrm{a}}$ & $4.57 \pm 0.32^{\mathrm{a}}$ & $3.99 \pm 0.21^{\mathrm{a}}$ & $4.73 \pm 0.30^{\mathrm{a}}$ & $4.14 \pm 0.31^{\mathrm{a}}$ \\
\hline & $\mathrm{U}$ & $2.71 \pm 0.17^{b}$ & $3.04 \pm 0.23^{\mathrm{b}}$ & $2.64 \pm 0.11^{\mathrm{b}}$ & $2.83 \pm 0.10^{\mathrm{b}}$ & $2.08 \pm 0.11^{\mathrm{b}}$ & $3.53 \pm 0.20^{\mathrm{b}}$ & $2.56 \pm 0.10^{\mathrm{b}}$ \\
\hline
\end{tabular}

Means with the same superscript $(\mathrm{a}, \mathrm{b})$ letter in the same treatment and week were not significantly different at $\mathrm{P} \leq 0.05$ using Duncan's Multiple Range Test.

$\mathrm{R}=$ Plants from stem cuttings which had some adventitious roots at the time of planting $\mathrm{U}=$ Plants from stem cuttings which did not have any root at the time of planting

Table 4. Comparison of the increment in total number of roots between plants whose stem cuttings had some adventitious roots at the time of planting and plants whose stem cuttings did not have any root at the time of planting across different treatments

\begin{tabular}{|c|c|c|c|c|c|c|c|c|}
\hline \multirow{2}{*}{$\begin{array}{l}\text { Weeks } \\
\text { after } \\
\text { planting }\end{array}$} & & \multicolumn{7}{|c|}{ Increment in the total number of roots } \\
\hline & & T1 & $\mathbf{T 2}$ & T3 & T4 & T5 & T6 & T7 \\
\hline \multirow[t]{2}{*}{ Week 0-2 } & $\mathrm{R}$ & $0.66 \pm 0.00^{\mathrm{b}}$ & $0.64 \pm 0.71^{b}$ & $1.07 \pm 0.03^{\mathrm{b}}$ & $0.66 \pm 0.29^{b}$ & $1.34 \pm 0.09^{\mathrm{b}}$ & $1.13 \pm 0.56^{\mathrm{b}}$ & $0.05 \pm 0.11^{\mathrm{b}}$ \\
\hline & $\mathrm{U}$ & $2.08 \pm 0.11^{\mathrm{a}}$ & $2.64 \pm 0.07^{\mathrm{a}}$ & $2.40 \pm 0.13^{\mathrm{a}}$ & $2.30 \pm 0.11^{\mathrm{a}}$ & $2.20 \pm 0.10^{\mathrm{a}}$ & $3.00 \pm 0.21^{\mathrm{a}}$ & $2.56 \pm 0.10^{\mathrm{a}}$ \\
\hline \multirow[t]{2}{*}{ Week 2-4 } & $\mathrm{R}$ & $0.73 \pm 0.04^{\mathrm{a}}$ & $0.61 \pm 0.43^{\mathrm{a}}$ & $0.65 \pm 0.12^{\mathrm{a}}$ & $0.44 \pm 0.00^{\mathrm{a}}$ & $0.35 \pm 0.02^{\mathrm{a}}$ & $0.47 \pm 0.00^{\mathrm{a}}$ & $1.05 \pm 0.37^{\mathrm{a}}$ \\
\hline & U & $0.63 \pm 0.20^{\mathrm{a}}$ & $0.40 \pm 0.35^{\mathrm{a}}$ & $0.24 \pm 0.07^{\mathrm{a}}$ & $0.53 \pm 0.01^{\mathrm{a}}$ & $0.00 \pm 0.00^{\mathrm{a}}$ & $0.53 \pm 0.03^{\mathrm{a}}$ & $0.00 \pm 0.00^{\mathrm{a}}$ \\
\hline
\end{tabular}

Means with the same superscript $(\mathrm{a}, \mathrm{b})$ letter in the same treatment and week were not significantly different at $\mathrm{P} \leq 0.05$ using Duncan's Multiple Range Test.

$\mathrm{R}=$ Plants from stem cuttings which had some adventitious roots at the time of planting

$\mathrm{U}=$ Plants from stem cuttings which did not have any root at the time of planting

Table 5: Comparison of the increment in root length between plants whose stem cuttings had some adventitious roots at the time of planting and plants whose stem cuttings did not have any root at the time of planting

\begin{tabular}{|c|c|c|c|c|c|c|c|c|}
\hline \multirow{2}{*}{$\begin{array}{l}\text { Weeks } \\
\text { after } \\
\text { planting }\end{array}$} & & \multicolumn{7}{|c|}{ Increment in root length $(\mathrm{cm})$} \\
\hline & & T1 & $\mathbf{T} 2$ & $\mathbf{T 3}$ & $\mathbf{T 4}$ & T5 & T6 & T7 \\
\hline \multirow[t]{2}{*}{ Week 0-2 } & $\mathrm{R}$ & $0.72 \pm 1.03^{b}$ & $0.52 \pm 0.81^{b}$ & $0.32 \pm 1.02^{\mathrm{b}}$ & $0.57 \pm 0.21^{\mathrm{b}}$ & $0.33 \pm 0.63^{b}$ & $0.26 \pm 0.60^{b}$ & $0.47 \pm 0.74^{b}$ \\
\hline & $\mathrm{U}$ & $2.16 \pm 0.05^{\mathrm{a}}$ & $1.87 \pm 1.74^{\mathrm{a}}$ & $2.16 \pm 0.10^{\mathrm{a}}$ & $1.81 \pm 1.75^{\mathrm{a}}$ & $1.55 \pm 1.43^{\mathrm{a}}$ & $2.79 \pm 0.15^{\mathrm{a}}$ & $2.41 \pm 0.08^{\mathrm{a}}$ \\
\hline \multirow[t]{2}{*}{ Week 2-4 } & $\mathrm{R}$ & $0.00 \pm 0.00$ & $0.00 \pm 0.00$ & $0.25 \pm 0.21^{\mathrm{a}}$ & $0.05 \pm 0.46^{\mathrm{a}}$ & $0.02 \pm 0.28^{\mathrm{a}}$ & $0.18 \pm 0.31^{\mathrm{a}}$ & $0.04 \pm 0.02^{\mathrm{b}}$ \\
\hline & $\mathrm{U}$ & $0.82 \pm 0.17^{\mathrm{a}}$ & $0.84 \pm 0.07^{\mathrm{a}}$ & $0.82 \pm 0.13^{\mathrm{a}}$ & $0.85 \pm 0.11^{\mathrm{a}}$ & $0.63 \pm 0.19^{\mathrm{a}}$ & $0.33 \pm 0.25^{\mathrm{a}}$ & $1.28 \pm 1.17^{\mathrm{a}}$ \\
\hline
\end{tabular}

Means with the same superscript $(\mathrm{a}, \mathrm{b})$ letter in the same treatment and week were not significantly different at $\mathrm{P} \leq 0.05$ using Duncan's Multiple Range Test.

$\mathrm{R}=$ Plants from stem cuttings which had some adventitious roots at the time of planting

$\mathrm{U}=$ Plants from stem cuttings which did not have any root at the time of planting 
culture medium (Pasternak et al., 2019). Our findings showed that a concentration of $2 \mathrm{mM} \mathrm{SA}$ (T6) would promote faster root initiation and extension of $P$. nigrum L. cv. 'Kuching'. The promotion of root initiation and extension by exogenous SA could be a result of induced auxin synthesis. According to Ludwig-Müller et al. (2005) and Pasternak et al. (2019), initiation and development of adventitious roots is induced by high cellular auxin synthesis at the root tip by SA. The above findings support current observations that addition of $2 \mathrm{mM} \mathrm{SA}$ in T6 hydroponic solution promoted faster root initiation and extension.

$P$. nigrum L. cuttings cultivated in Hoagland solution supplemented with $0.005 \mathrm{mM}$ potassium silicate solution (T4) also showed faster root initiation and extension in the present study. Although silicon ( $\mathrm{Si}$ ) is not considered an essential nutrient for plants, improved beneficial effects to plants in response to $\mathrm{Si}$ fertilization is welldocumented (Laane, 2018), including a regulatory role in the uptake of other plant nutrients plus improved hydraulic conductance (Ma \& Yamaji, 2006; Liang et al., 2007; Deshmukh et al., 2017). For example, applications of $0.05 \%, 0.1 \%$ and $0.2 \%$ potassium silicate increased nutrient uptake of $\mathrm{N}, \mathrm{P}, \mathrm{K}$ and $\mathrm{Mg}$ in sapkota date palms (Al-wasfy, 2013). Hence, enhanced nutrient absorption might have contributed to the fast root initiation and extension by the black pepper cuttings in Hoagland solution supplemented with $0.005 \mathrm{mM}$ potassium silicate solution (T4).

Hoagland solution is a standard plant medium which supplies all the essential plant nutrients in minimum quantities for healthy plant growth (Hoagland \& Arnon, 1938). Over the years, Hoagland solution has been commonly used as a baseline for soilless plant cultivation (Zabel et al., 2019). Based on the results of this study, Hoagland solution (T1) promoted the highest root extension. However, Hoagland solution had to be supplemented with $2 \mathrm{mM}$ SA solution (T6) or $0.005 \mathrm{mM}$ potassium silicate solution (T4) for root initiation to be fast.

The fewest number of roots and shortest root length observed in Hoagland solution supplemented with $6 \mathrm{~mL}$ of $1 \mathrm{M} \mathrm{Ca}\left(\mathrm{NO}_{3}\right)_{2} \cdot 4 \mathrm{H}_{2} \mathrm{O}$ (T3) and $0.005 \mathrm{mM}$ potassium silicate solution (T5), respectively, which were observed in the present study could have been caused by the common nutrient salt, $\mathrm{Ca}\left(\mathrm{NO}_{3}\right)_{2} \cdot 4 \mathrm{H}_{2} \mathrm{O}$. Although it is a vital nutrient for plant growth, calcium is reactive towards sulphate when in concentrated liquids, and forms calcium sulphate or gypsum, which precipitates out of solution. Moreover, Zhao et al. (2008) reported that sulphur application increased the root number of soybean. Therefore, the observed poor root growth of hydroponic $P$. nigrum L. in T3 and T5 could have been a result of calcium-induced deficiencies of sulfur as high lightened by Mutters et al. (2010).

Root growth is critical to the survival and establishment of stem cuttings. Newly planted stem cuttings are susceptible to stress if they have limited or no access to a proper water and nutrient balance from the soil, arising from delayed root development or insufficient adventitious root growth. According to Steven (2005), the ability of a new plant to overcome planting stress is affected among other factors by its root system size and distribution. Based on the findings of this study, $\mathrm{R}$ cuttings showed slight advantage initially in number of roots, but this advantage was eventually lost. The U cuttings outperformed in the increment of root length especially in Hoagland solution supplemented with $6 \mathrm{~mL}$ of $1 \mathrm{M} \mathrm{Ca}\left(\mathrm{NO}_{3}\right)_{2} \cdot 4 \mathrm{H}_{2} \mathrm{O}$ solution with $2 \mathrm{mM}$ SA solution (T7) than R cuttings (Table 5). Root suberisation may also be a contributing factor to the better root growth in plants whose stem cuttings did not have any root at the time of planting than plants whose stem cuttings had some adventitious roots at the time of planting.

Current findings corroborate with previous results of Steven (2005) which reported that unsuberised roots posed little resistance to nutrient plus water uptake and further root growth. Keeping other factors constant, new/or unsuberised roots facilitate an efficient water and nutrient uptake by the plant whereas older/suberized roots impede efficient nutrient and water uptake by the plant. Hence increased development of new (unsuberised) roots with time in plants from $U$ cuttings, translated into improved nutrient uptake, more roots and lengthier roots initially than in plants from R cuttings. Steven (2005) also observed that newly developed roots have high water and nutrient uptake capability.

\section{CONCLUSION}

The current study showed that Hoagland solution supplemented with potassium silicate at $0.005 \mathrm{mM}$ (T4), and SA at $2 \mathrm{mM}$ (T6) promoted faster root 
growth. Stem cuttings which did not have any root at the time of planting favoured faster increment in root number and extension. The present study assessed root growth of $P$. nigrum L. cv. 'Kuching' stem cuttings in a deep-water culture hydroponic system for a total period of 4 weeks. To our knowledge, this is the first study documenting the growth of $P$. nigrum $L$. in a hydroponic system. We thus recommend that further studies are necessary to (i) establish the performance of these plants after transfer to field conditions (ii) compare with the traditional method of planting material preparation, i.e. sown with sand.

\section{ACKNOWLEDGEMENTS}

The authors thank the Islamic Development Bank (IsDB) for providing Babirye Khadijah a full Masters scholarship to study at Universiti Putra Malaysia. This research was funded by GPIPB/2018/9557607.

\section{REFERENCES}

Ahmad, N., Fazal, H., Abbasi, B.H., Farooq, S., Ali, M. \& Khan, M.A. (2012). Biological role of Piper nigrum L. (black pepper): A review. Asian Pacific Journal of Tropical Biomedicine, (2): 1945-1953.

Al-Wasfy, M.M. (2013). Response of Sakkoti date palms to foliar application of royal jelly, silicon and vitamins B. Journal of American Science, (9): 315321.

Amalfitano, C., Del Vacchio, L., Somma, S., Cuciniello, A. \& Caruso, G. (2017). Effects of cultural cycle and nutrient solution electrical conductivity on plant growth, yield, and fruit quality of "Friariello" pepper grown in hydroponics. Horticultural Science, (44): 91-98.

Andreas, R., Georgia, N., Constantinos, K., Nikolaos K. \& Dimitrios, S. (2019). Effects of temperature and grafting on yield, nutrient uptake, and water use efficiency of a hydroponic sweet pepper crop. Journal of Agronomy, 9: 110. Available from: DOI: 10.3390/agronomy9020110 (Accessed: 28 May 2019).

Ann, Y.C. (2012). Determination of nutrient uptake characteristic of black pepper (Piper nigrum L.). Agricultural Science and Technology, (2): 1091-1099.

Deshmukh, R.K., Ma, J.F. \& Bélanger, R.R. (2017). Role of silicon in plants. Frontiers in Plant Science, 8: 1858.
De Souza, F.G., De Freitas, F.G., Cavalcante, A.R., Chaves, L.H.G., Fernandes, J.D. \& Júnior, J.A.S. (2018). Growth of pepper under different concentration of the solutions used in the hydroponic system. Agricultural Sciences, 9: 925935. Available from: DOI: https://doi.org/10.4236/ as.2018.98064. (Accessed: 13 April 2019).

De Waard, P.W.F. \& Zeven, D.C. (1969). Outlines of perennial crop breeding. In Ferwaeeda, F.P. \& Wit, F. (Eds.), Pepper. Pp 409-426.

Eduardo, C., Carlos, A.C., Ana, T.L. \& Maria, I.S.L. (2015). Coupling microalgal cultures with hydroponics: prospection for clean biotechnology processes. Journal of Algal Biomass Utilization, 6(1): 88- 94.

Graves, C.J. (1983). The nutrient film technique. Horticultural Reviews, 5(1): 1-44.

Hoagland, D.R. \& Arnon, D.I. (1938). The water-culture method for growing plants without soil. Berkeley, California: University of California Publication. $\mathrm{Pp}$ $1-32$.

Islam, M.Z., Mele, M.A., Baek, J.P. \& Kang, H. (2018). Iron, iodine and selenium effects on quality, shelf life and microbial activity of cherry tomatoes. Notulae Botanicae Horti Agrobotanici Cluj-Napoca, 46: 388-392. Available from: DOI: 10.1186/ s41182-018-0085-x. (Accessed: 16 October 2019).

Kevin, S.M.T., Ahmed, O.H., Khew, C.Y. \& Zehnder, J.A.M. (2018). Introducing natural farming in black pepper (Piper nigrum L.) cultivation. International Journal of Agronomy, 2018: 1-6. Available from: DOI:10.1155/2018/931 2537 (Accessed: 21 April 2019).

Khan, M.I.R., Fatma, M., Per, T.S., Anjum, N.A. \& Kahn, N.A. (2015). Salicylic acid-induced abiotic stress tolerance and underlying mechanisms in plants. Frontiers in Plant Science, 6: 462. Available from: DOI:10. 3389/fpls.2015.00462 (Accessed: 01 November 2019).

Laane, H.M. (2018). The effects of foliar sprays with different silicon compounds. Plants, 7(2): 45. Available from: DOI:10.3390/plants702004 5 (Accessed: 15 February 2020).

Lee, J.Y., Rahman, A., Azam, H., Kim, H.S. \& Kwon, M.J. (2017). Characterizing nutrient uptake kinetics for efficient crop production during Solanum lycopersicum var. cerasiforme Alef. growth in a closed indoor hydroponic system. PLoS ONE, 12(5), e0177041. Available from: https://doi.org/10.1371/ journal.pone. 0177041. (Accessed: 12 April 2020). 
Liang, Y.C., Sun, W.C., Zhu, Y.G. \& Christie, P. (2007). Mechanisms of silicon-mediated alleviation of abiotic stresses in higher plants: A review. Environmental Pollution, 147: 422- 428.

Libia, I.T. \& Fernando, C.G. (2012). Nutrient solutions for hydroponic systems. In: Asao T. (ed.) Hydroponics - A Standard Methodology for Plant Biological Researches. Available from: DOI: 10.5772/37578 (Accessed: 08 May 2019).

Ludwig-Müller, J., Vertocnik, A. \& Town, C.D. (2005). Analysis of indole-3-butyric acid-induced adventitious root formation on Arabidopsis stem segments. Journal of Experimental Botany, 56: 2095-2105. Available from: DOI:10.1093/jxb/eri 208 (Accessed: 19 June 2019).

Ma, J.F. \& Yamaji, N. (2006). Silicon uptake and accumulation in higher plants. Trends in Plant Science, 11: 392-397.

Marschner, H. (1995). Mineral Nutrition of Higher Plants. New York, USA, Academic Press.

Meghwal, M. \& Goswami, T.K. (2013). Piper nigrum and piperine: an update. Phytotherapy Research, (8): 1121-1130.

Megir, G. \& Paulus, A.D. (2011). Pepper Production Technology in Malaysia. Malaysian Pepper Board, Sarawak, Malaysia.

Mutters, R.G., Greer, C.A. \& Horwath, W.R. (2010). Rice Nutrient Management in California. University of California: University of California Division of Agriculture and Natural Resources (UCANR) Publications.

Nerrisa, P., Mirasol, P., Tin, M.A. \& Thomas, O. (2018). Nutrient uptake and distribution in black pepper. Better Crops, 102(4).

Pasternak, T., Groot, E.P., Kazantsev, F.V, Teale, W., Omelyanchuk, N., Kovrizhnykh, V., Palme, K. \& Mironova, V.V. (2019). Salicylic acid affects root meristem patterning via auxin distribution in a concentration-dependent manner. Plant Physiology. Available from: DOI:10.1104/pp.19. 00130 (Accessed: 17 August 2019).

Pignata, G., Casale, M. \& Nicola, S. (2017). Water and nutrient supply in horticultural crops grown in soilless culture: resource efficiency in dynamic and intensive systems. In: Tei, F., Nicola, S. \& Benincasa, P. (eds.) Advances in Research on Fertilization Management of Vegetable Crops. Cham Springer publication. pp.183-219.

Pregitzer K.S \& King, J.S. (2005). Effects of soil temperature on nutrient uptake. In: BassiriRad H. (eds) Nutrient acquisition by plants: An ecological perspective. Ecological Studies, 181: 277-310. Springer, Berlin, Heidelberg. Available from: DOI:10.1007/3-540-27675-0_10 (Accessed: 30 November 2020).

Rachelle, L.C., Naresh, V.T., Andrew, M.G. \& Derek, S._(2009). Biophysical interactions in a short rotation willow intercropping system in southern Ontario, Canada. Agriculture, Ecosystems \& Environment, 131(1-2): 61-69. Available from: DOI:10.1016/j. agee.2009. 01.018 (Accessed: 11 January 2020).

Ravindra, H., Manu, G.T., Latha, M., Mukesh, S., Murali, R. \& Narasimhamurthy, H.B. (2014). Incidence of root-knot nematode (Meloidogyne incognita) in black pepper in Karnataka. Journal of Entomology and Nematology, 6(4): 51-55. Available from: DOI:10.5897/jen2013. 0089 (Accessed: 23 March 2019).

Sambo, P., Nicoletto, C., Giro, A., Pii, Y., Valentinuzzi, F., Mimmo, T., Paolo, L., Guido, O., Fabrizio, M., Stefania, A., Roberto, T. \& Cesco, S. (2019). Hydroponic solutions for soilless production systems: Issues and opportunities in a smart agriculture perspective. Frontiers in Plant Science, 10(923). Available from: DOI:10.3389/fpls.2019.00 923 (Accessed: 14 March 2019).

Sivaraman, K., Kandiannan, P.K.V. \& Thankaman, C.K. (1999). Agronomy of black pepper (Piper nigrum L.) - a review. Journal of Spices and Aromatic Crops, (8)1: 1-18.

Spehia, R.S., Devi, M., Singh, J., Sharma, S., Negi, A., Singh, S., Sukhpreet, S., Nirmla, C., Sharma, D. Sharma, J.C. (2018). Lettuce growth and yield in Hoagland Solution with an organic concoction. International Journal of Vegetable Science, Pp110. Available from: DOI:10.1080/19315260.2018. 1452815 (Accessed: 10 April 2019).

Srinivasan, V., Dinesh, R., Hamza, S. \& Parthasarathy, V.A. (2007). Nutrient management in black pepper (Piper nigrum L.). CAB Reviews: Perspectives in Agriculture, Veterinary Science, Nutrition and Natural Resources, 2(62): 1-14.

Srinivasan, V., Dinesh, R., Krishnamurthy, K.S. \& Hamza, S. (2012). Nutrition and physiology. In Singh, H.P., Parthasarathy, V.A. \& Srinivasan, V. (eds.), Piperaceae Crops: Production \& utilization. Westville Publishing House. Pp 101-121.

Steven, C.G. (2005). Importance of root growth in overcoming planting stress. New Forests, 30: 273294. Available from: DOI: 10.1007/s 11056-0048303-2 (Accessed: 10 September 2019). 
Valentinuzzi, F., Pii, Y., Vigani, G., Lehmann, M., Cesco, S. \& Mimmo, T. (2015). Phosphorus and iron deficiencies induce a metabolic reprogramming and affect the exudation traits of the woody plant Fragariaxananassa. Journal of Experimental Botany, 66: 6483-6495. Available from: DOI: 10.1093/jxb/ erv364 (Accessed: 24 February 2020).

Vicente, M.R. \& Plasencia, J. (2011). Salicylic acid beyond defense: its role in plant growth and development. Journal of Experimental Botany, 62(10): 3321-3338. Available from: DOI:10.1093/ jxb/err031 (Accessed: 07 July 2019).

Vijayakumar, K.R., Unni, P.N. \& Vasudevan, V. K. (1984). Physiological changes in pepper (cv. panniyur-1) associated with water logging. Agricultural Research Journal, 22(1): 96-99.

Vijayakumar, K.R. \& Mammen, G. (1990). Effect of contact shading and yield performance in black pepper. In Proceedings of the International Congress of Plant Physiology, February 15-20, 1998: Society of Physiology and Biochemistry. pp. 935-938.

Wada, T. (2019). Theory and technology to control the nutrient solution of hydroponics. Part I: Efficient and effective vegetable cultivation technologies to enhance productivity and quality. In: Masakazu, A., Hirokazu, F. \& Teruo, W (eds.) Plant Factory Using Artificial Light: Adapting to Environmental Disruption and Clues to Agricultural Innovation. $1^{\text {st }}$ edition: Elsevier. Pp. 5-14. Available from: DOI:10.1016/b978-0-12-813973-8.00001-4 (Accessed: 31 July 2021).
Wahid, P. \& Sitepu, D. (1987). Current Status and Future Prospect of Pepper Development in Indonesia. Food and Agricultural organization, Bangkok: Regional office for Asia and Pacific. pp 92-103.

Wani, A.B., Chadar, H., Wani, A.H., Singh, S. \& Upadhyay, N. (2016). Salicylic acid to decrease plant stress. Environmental Chemistry Letters, 15(1): 101-123. Available from: DOI: 10.1007/s 10311-016-0584-0 (Accessed: 20 November 2019).

Yang, W., Zhu, C., Ma, X., Li, G., Gan, L., Ng, D. \& Xia, K. (2013). Hydrogen peroxide is a second messenger in the salicylic acid-triggered adventitious rooting process in mung bean seedlings. PLoS One, 8, e84580. Available from: DOI: 10.1371/journal.pone.0084580 (Accessed: 04 January 2020).

Zabel, P., Bornemann, G., Tajmar, M. \& Schubert, D. (2019). Yield of dwarf tomatoes grown with a nutrient solution based on recycled synthetic urine. Life Sciences in Space Research, 20: 6271. Available from: DOI: 10.1016/j.lssr.2019.01. 001 (Accessed: 28 May 2020).

Zhao, Y., Xiao, X., Bi, D. \& Hu, F. (2008). Effects of sulfur fertilization on soybean root and leaf traits, and soil microbial activity. Journal of Plant Nutrition, 31: 473-483.

Zhigang, L., Aiqin, L., Huasong, W., Lehe, T., Yuzhou, L., Yafeng, G., Shiwei, S. \& Liwei, S. (2010). Influence of temperature, light and plant growth regulators on germination of black pepper (Piper nigrum L.) seeds. African Journal of Biotechnology, 9(9): 1354-1358. 